\title{
Inhibition of prostaglandin action and bone resorption by copper
}

\author{
J. M. KATZ, ${ }^{1}$ S. J. M. SKINNER ${ }^{2}$ T. WILSON ${ }^{2}$ AND D. H. GRA Y
}

From the ${ }^{1}$ Department of Surgery, School of Medicine, University of Auckland, Auckland, and the ${ }^{2}$ Postgraduate School of Obstetrics and Gynaecology, University of Auckland, Auckland, New Zealand

SUMMARY Mouse calvaria were maintained in organ culture without serum additives. The effects of $\mathrm{Cu}^{2+}$ on bone resorption and on the synthesis and action of prostaglandins were studied. Non-toxic concentrations of copper sulphate $(5 \mu \mathrm{M})$ were found to decrease active resorption, measured by ${ }^{45} \mathrm{Ca}$ release, to $54 \%$ control values $(\mathrm{p}<0.001)$, while prostaglandin $\mathrm{F}$ (PGF), prostaglandin $E_{2}\left(P G E_{2}\right)$, and 6-keto-prostaglandin $F_{1 \alpha}$, (6-keto-PGF $\left.F_{1 \alpha}\right)$, determined by radioimmunoassay, were increased above controls $(\mathrm{p}<0 \cdot 05)$. These effects of $\mathrm{Cu}^{2+}$ on prostaglandin synthesis were confirmed by the isolation and quantitation of $\left[{ }^{3} \mathrm{H}\right]$-labelled metabolites released from calvaria which had been pre-labelled with $\left[{ }^{3} \mathrm{H}\right]$-arachidonic acid. $\mathrm{PGE}_{2}, \mathrm{PGF}_{2 \alpha}$, 6-keto-PGF $1 \alpha$, and thromboxane $\mathrm{B}_{2}\left(\mathrm{TxB}_{2}\right)$ were all higher in copper-exposed calvaria, but their relative amounts remained unchanged. There was no evidence that $\mathrm{Cu}^{2+}$ influenced the mobilisation of $\left[{ }^{3} \mathrm{H}\right]$-arachidonic acid from prelabelled calvaria. The stimulation of bone resorption by exogenous prostaglandins was decreased in the presence of $\mathrm{Cu}^{2+}(\mathrm{p}<0 \cdot 005)$, while parathormone-mediated bone resorption was virtually unaffected. $\mathrm{Cu}^{2+}$ also increased the inhibition of bone resorption seen with indomethacin $(p<0 \cdot 05)$. In addition to the effects of the metal on prostaglandin action $\mathrm{Cu}^{2+}$ also decreased $\beta$-glucuronidase activity in the media to $86 \%$ of the control values $(\mathrm{p}<0 \cdot 001)$. The action of $\mathrm{Cu}^{2+}$ in inhibiting bone resportion in vitro appears complex but does not involve inhibition of prostaglandin synthesis. It is likely that $\mathrm{Cu}^{2+}$ has more than one inhibitory locus.

Key words: prostaglandins $\mathrm{F}$ biosynthesis, prostaglandins $\mathrm{E}$ biosynthesis, copper pharmacodynamics, rheumatoid arthritis, bone resorption.

Elevated serum copper levels are present in a number of inflammatory conditions including rheumatoid arthritis, ${ }^{1}$ ankylosing spondylitis, ${ }^{2}$ psoriasis, ${ }^{3}$ adjuvant arthritis, ${ }^{4}$ and periodontal disease. ${ }^{5}$ Despite these observations a number of hypotheses have proposed an 'anti-inflammatory' role for endogenous copper ${ }^{67}$ and copper is used in various forms as an anti-inflammatory agent. ${ }^{89}$

Previous studies in this laboratory have shown that copper is a potent inhibitor of bone resorption in vitro. ${ }^{10}$ While its mechanism of action is unknown in bone, in cell-free systems there is evidence that copper alters prostaglandin biosynthesis, enhancing

Accepted for publication 21 June 1984.

Correspondence to Dr J. M. Katz, Department of Surgery, School of Medicine, University of Auckland, Private Bag, Auckland, New Zealand.
$\mathrm{PGF}_{2 \alpha}$ production at the expense of $\mathrm{PGE}_{2}{ }^{11}{ }^{11}$ Prostaglandins, particularly those of the $E$ series and the $\mathrm{F}$ series, are known to stimulate bone resorption in vitro, ${ }^{12}$ and the prostaglandin synthetase system has been identified in cultured bone. ${ }^{13}$ The following study examines the possibility that the decreased bone resorption observed in the mouse calvarium in the presence of copper in vitro is associated with altered prostaglandin biosynthesis or action.

\section{Material and methods}

ORGAN CULTURE OF BONE

The organ culture procedure has been described in detail. ${ }^{10} 14$ Unless otherwise stated, calvaria were dissected from six-day old mice and then pooled and randomised into treatment groups and one control group. The bones were cultured singly in $5 \mathrm{ml} \mathrm{Gibco}$ 
199 medium (without serum additives) and incubated in an atmosphere of $20 \% \mathrm{O}_{2}, 5 \% \mathrm{CO}_{2}$, and $75 \% \mathrm{~N}_{2}$. Calvaria were precultured for $24 \mathrm{~h}$ after dissection and then cultured in fresh medium for a further $48 \mathrm{~h}$ under experimental conditions. This procedure removes the large quantities of prostaglandins released after dissection and renders the system sensitive to stimulators of resorption. ${ }^{14}$ Indomethacin and prostaglandins were added to the culture medium in absolute ethanol solutions. The alcohol added to both control and treated bones did not exceed a final concentration of $0.3 \%$ and as such had no effect on active resorption.

\section{DETERMINATION OF ACTIVE RESORPTION}

Resorption of bone was determined by the release of ${ }^{45} \mathrm{Ca}$ into the medium from calvaria obtained from mice which were prelabelled with $5 \mu \mathrm{Ci} 45$ $\mathrm{CaCl}_{2}$ at 2 days of age. Non-cell-mediated release of ${ }^{45} \mathrm{Ca}$ was determined from four calvaria of each litter, which were killed by triple freezing and thawing prior to incubation. The percentage active resorption $\left({ }^{45} \mathrm{Ca}\right)$ was quantified and calculated as described. ${ }^{10}$

MEASUREMENT OF PROSTAGLANDINS

The culture medium was sampled to determine ${ }^{45} \mathrm{Ca}$ release and then acidified ( $\mathrm{pH}$ 3.0) prior to extraction of the prostanoids. Prostaglandin F (PGF), prostaglandin $\mathrm{E}_{2}\left(\mathrm{PGE}_{2}\right)$, and 6-keto-prostaglandin $F_{1 \alpha}$ (6-keto-PGF $F_{1 \alpha}$ ) were measured by specific radioimmunoassays. The method of extraction, assay procedures and cross-reactivity data for PGF and $\mathrm{PGE}_{2}$ radioimmunoassays have been described in detail. ${ }^{14}{ }^{15}$ Extraction with ethyl acetate improved the recovery of 6-keto-PGF $1 \alpha$, and was therefore used in preference to diethyl ether when this prostanoid was assayed. An antiserum to 6-ketoPGF $_{1 \alpha}$ conjugated with bovine serum albumin (BSA) was raised in rabbits. This antiserum crossreacted $14 \cdot 7 \%$ with $\mathrm{PGD}_{2}, 9 \cdot 3 \%$ with $\mathrm{PGF}_{2 \alpha}, 8 \cdot 4 \%$ with $\mathrm{PGE}_{2}$, and $22.9 \%$ with 13, 14-dihydro$\mathrm{PGF}_{2 \alpha} \cdot{ }^{15}$ Samples were redissolved in phosphate buffer $(0 \cdot 1 \mathrm{M}) \mathrm{pH} 7 \cdot 4$, containing $\mathrm{NaCl}(0 \cdot 15 \mathrm{~m})$, $\mathrm{NaN}_{3}(0.015 \mathrm{M})$, and gelatin $(0.1 \%)$ and assayed in duplicate. The assay method and cross-reactivity data are fully described. ${ }^{15}$ The standard curve was constructed over a range of $0-500 \mathrm{pg}$. Blank values of $20 \cdot 8 \pm 1.8$ (SD) pg were obtained by extracting medium and processing it as for the samples.

Further purification of the samples was not required unless exogenous arachidonic acid $\left(10^{-5}\right.$ M) was present, resulting in high blank values. Column chromatography of these samples with silicic acid eliminated this non-specific binding effect. All results presented have been corrected for recovery from extraction.
UPTAKE OF $\left({ }^{3} \mathrm{H}\right)$ ARACHIDONIC ACID INTO CALVARIA

$\left[{ }^{3} \mathrm{H}\right]$ Arachidonic acid $\left(\left[{ }^{3} \mathrm{H}\right]-\mathrm{AA}\right)$ was purified by column chromatography prior to use. ${ }^{10}$ The following procedure optimised the uptake of $\left[{ }^{3} \mathrm{H}\right]-\mathrm{AA}$ into bone. After dissection each whole calvarium was inverted and cultured for $24 \mathrm{~h}$ in $5 \mathrm{ml}$ medium containing no serum additives. The cranial space was filled with $80 \mu \mathrm{l}$ medium containing $2-5 \mu \mathrm{Ci}$ $\left[{ }^{3} \mathrm{H}\right]-\mathrm{AA}$ to give a concentrated source of isotope close to the tissue surface. After $24 \mathrm{~h}$ incubation with the isotope the tissue was rinsed to remove excess $\left[{ }^{3} \mathrm{H}\right]-\mathrm{AA}$ and then dissected into paired hemicalvaria. One half of each calvarium was used as a control bone and the other cultured in medium containing copper sulphate $(5 \mu \mathrm{M})$. Two calvaria were cultured per $5 \mathrm{ml}$ medium. After $48 \mathrm{~h}$ the medium from each treatment group was pooled, the radioactivity estimated, and the remaining media frozen rapidly. Calvaria from each treatment group were pooled, demineralised ${ }^{17}$ and solubilised to estimate total incorporation of labelled arachidonic acid and to ensure uniform uptake of isotope between treatment groups.

PURIFICATION AND SEPARATION OF LABELLED PROSTANOIDS

Twenty $\mu \mathrm{g}$ of each of unlabelled $\mathrm{PGE}_{2}, \mathrm{PGF}_{2 \alpha}$, 6-keto-PGF ${ }_{1 \alpha}$, and thromboxane $\mathrm{B}_{2}\left(\mathrm{TxB}_{2}\right)$ was added to each medium sample to optimise recoveries. Medium (15 ml) was then acidified ( $\mathrm{pH} \mathrm{3.4)}$ with formic acid and loaded on to a $\mathrm{C}_{18}$ Sep Pak (Waters Assocs, Mass, USA), washed with (1) $\mathrm{H}_{2} \mathrm{O}$, (2) $12 \%$ ethanol (3) petroleum ether, and the prostanoids eluted with methyl acetate, similar to the method of Powell. ${ }^{16}$ Excess solvent was removed with oxygen-free dry nitrogen and the residue redissolved in $200 \mu \mathrm{l}$ of high-performance liquid chromatography (HPLC) column solvent (see below). Prostanoids were separated by HPLC using a $\mathrm{C}_{18} \mu$-Bondapak column and instrumentation from Waters Associates. The separation method was based on that of Alam et al. ${ }^{18}$ The arachidonic acid metabolites were eluted isocratically with a solvent sytem consisting of acetonitrile:water:benzene:acetic acid (230:767:2:1) at a flow rate of $1 \mathrm{ml} / \mathrm{min}$. All fractions were collected and counted. Results presented are not corrected for recovery from the column. Authentic $\left[{ }^{3} \mathrm{H}\right]-\mathrm{PGE}_{2},\left[{ }^{3} \mathrm{H}\right]-\mathrm{PGF}_{2 \alpha},\left[{ }^{3} \mathrm{H}\right]-6-$ keto-PGF ${ }_{1 \alpha}$, and $\left[{ }^{3} \mathrm{H}\right]-\mathrm{TxB}_{2}$ were mixed with $20 \mu \mathrm{g}$ of each appropriately unlabelled prostanoid and used as standards to identify the major metabolites. The recoveries were from $69 \cdot 5$ to $80 \cdot 0 \%$. $\left[{ }^{3} \mathrm{H}\right]$-AA was incubated in the absence of calvaria with and without $\mathrm{Cu}^{2+}$ under the normal culture conditions and processed as described above. No significant 
radioactive material was eluted by HPLC with retention times corresponding to 6-keto-PGF ${ }_{1 \alpha}$, $\mathrm{TxB}_{2}, \mathrm{PGF}_{2 \alpha}$, or $\mathrm{PGE}_{2}$.

\section{MATERI A LS}

Medium 199 was from Grand Island Biological Company, Grand Island, New York. Indomethacin, activated charcoal, dextran, sodium azide, 4-methyl umbelliferone, and 4-methylumbelliferyl glucuronide were from the Sigma Chemical Co., St Louis, USA. The radioactive chemicals ${ }^{45} \mathrm{CaCl}_{2}(59 \mu \mathrm{g} /$ $\mathrm{mCi}),\left[5,6,8,12,14,15(\mathrm{n}){ }^{3} \mathrm{H}\right] \mathrm{PGE}_{2}(160 \mathrm{Ci} / \mathrm{mmol})$, $\left[9-{ }^{3} \mathrm{H}\right] \mathrm{PGF}_{2 \alpha}(19 \cdot 4 \mathrm{Ci} / \mathrm{mmol}),[5,6,8,9,11,12,14,15,-$ $\left.{ }^{3} \mathrm{H}\right]$ arachidonic acid $(100 \mathrm{Ci} / \mathrm{mmol})$ were purchased from the Radiochemical Co., Amersham, England. $\left[5,8,9,11,12,14,15(\mathrm{n}){ }^{3} \mathrm{H}\right] \quad 6$-keto-PGF $1 \alpha \quad(120 \mathrm{Ci} /$ mmol) was supplied by New England Nuclear, Boston, USA. Unlabelled prostaglandins were kindly provided by Dr J. E. Pike, Upjohn Co., Kalamazoo, USA. Antisera to PGF and to 6-keto-PGF ${ }_{1 \alpha}$ were kindly supplied by Professor G. C. Liggins and antiserum to $\mathrm{PGE}_{2}$ was purchased from the Pasteur Institute, Paris. All other solvents and reagents used were of analytical grade. Mice were Charles River CD-1 (an outbred strain).

\section{STATISTICS}

Results are presented as mean values \pm SEM. The data were evaluated by analysis of variance followed by Spjøtvoll and Stoline's T method. ${ }^{19}$ Student's $t$ test was used for unpaired data as appropriate.

\section{Results}

Previous in-vitro studies have shown that $\mathrm{Cu}^{2+}$ inhibits bone resorption in a dose-dependent manner. ${ }^{10}$ In the experiment described below $\mathrm{CuSO}_{4}, 5 \mathrm{H}_{2} \mathrm{O}$, used at a concentration of $5 \mu \mathrm{M}$, did not influence DNA and protein synthesis within calvaria. ${ }^{10}$ The quantities of prostaglandins released into the medium from calvaria cultured with and without $\mathrm{Cu}^{2+}(5 \mu \mathrm{M})$ are shown in Table 1 . The

Table 1 Prostaglandin production from calvaria in the presence of copper

\begin{tabular}{llccl}
\hline & $\begin{array}{l}P G F \\
(p g / b o n e)\end{array}$ & $\begin{array}{l}P G E_{2} \\
(p g / b o n e)\end{array}$ & $\begin{array}{l}\text { 6-keto-PGF } \\
(p g / \text { bone })\end{array}$ & $\begin{array}{l}\% \text { active } \\
\text { resorption } \\
\left(^{45} \text { Ca }\right)\end{array}$ \\
\hline Control & $506 \pm 34$ & $760 \pm 108$ & $995 \pm 145$ & $25 \cdot 5 \pm 0 \cdot 5$ \\
$\mathrm{Cu}^{2+}$ & $696 \pm 65^{* *}$ & $1132 \pm 119^{* *}$ & $1393 \pm 97^{*}$ & $13 \cdot 7 \pm 0 \cdot 6^{* *}$
\end{tabular}

Calvaria were precultured $24 \mathrm{~h}$, then cultured in fresh medium with or without $\mathrm{Cu}^{2+}(5 \mu \mathrm{M})$ for $48 \mathrm{~h}$.

Results are shown as mean \pm SEM. Ten calvaria in each treatment (from two litters).

Significantly different from control; ${ }^{*} \mathrm{p}<0 \cdot 05,{ }^{* *} \mathrm{p}<0 \cdot 02$. amounts of PGF, $\mathrm{PGE}_{2}$, and 6-keto-PGF $1 \alpha$ released from calvaria were increased significantly in the presence of $\mathrm{Cu}^{2+}(\mathrm{p}<0 \cdot 05)$, while active resorption was decreased to $54 \%$ of controls $(p<0 \cdot 001)$. The relative amounts of the prostaglandins measured were similar in control and $\mathrm{Cu}^{2+}$-treated calvaria and were in the order 6-keto-PGF PG $_{1 \alpha}>\mathrm{PGE}_{2}>$ PGF. $\mathrm{Cu}^{2+}(5 \mu \mathrm{M})$ did not appear selectively to enhance the production of any one of the prostaglandins measured (Table 1).

The addition of arachidonic acid $\left(10^{-5} \mathrm{M}\right)$ to calvaria caused increased production of both PGF and $\mathrm{PGE}_{2}$ compared with the amounts released from calvaria cultured without arachidonic acid. This increase in PGF and $\mathrm{PGE}_{2}$ was concomitant with a rise in active resorption. ${ }^{14}$ When calvaria were cultured with arachidonic acid in the presence of $\mathrm{Cu}^{2+}$, active resorption was significantly lowered, while PGF production increased above that seen with arachidonic acid alone $(\mathrm{p}<0 \cdot 001)$, and $\mathrm{PGE}_{2}$ levels were not significantly different (Table 2).

The results obtained by radioimmunoassay measurements (Tables 1 and 2) were confirmed by isolation and measurement of radioactive metabolites released by calvaria prelabelled with $\left[{ }^{3} \mathrm{H}\right] \mathrm{AA}$. The average uptake of labelled arachidonic acid in two separate experiments, each with one control and one copper-treated group of calvaria, was $17 \cdot 5 \pm 1 \cdot 2 \%$. During the subsequent $48 \mathrm{~h}, 10 \cdot 5 \%$ of this radioactivity was released into the medium from control bones and $10.9 \%$ was released from bones cultured with $5 \mu \mathrm{M} \mathrm{Cu}^{2+}$. Separation of the prostanoids in media using HPLC (see 'Methods') showed peaks of radioactive labelled compounds corresponding to 6-keto-PGF $1 \alpha, \mathrm{TxB}_{2}, \mathrm{PGF}_{2 \alpha}$, and $\mathrm{PGE}_{2}$ as identified by means of authentic $\left[{ }^{3} \mathrm{H}\right]$-labelled compounds. There were no major unidentified peaks of radioactive labelled compounds present. There was evidence for small amounts of radioactive

Table 2 Prostaglandin production from calvaria incubated with arachidonic acid and copper

\begin{tabular}{lccl}
\hline & $\begin{array}{l}P G F \\
(p g / \text { bone })\end{array}$ & $\begin{array}{l}P G E_{2} \\
(p g / b o n e)\end{array}$ & $\begin{array}{l}\% \text { active } \\
\text { resorption } \\
(+5.5 a)\end{array}$ \\
\hline $\begin{array}{l}\text { Untreated } \\
\begin{array}{l}\text { Arachidonic acid } \\
\left(10^{-5} \mathrm{M}\right)\end{array}\end{array}$ & $440 \pm 64$ & $859 \pm 72$ & $20 \cdot 9 \pm 0 \cdot 9$ \\
$\begin{array}{l}\text { Arachidonic acid }\left(10^{-5} \mathrm{M}\right) \\
\text { plus } \mathrm{Cu}^{2+}\end{array}$ & $1189 \pm 56^{*}$ & $5526 \pm 530$ & $28 \cdot 2 \pm 1 \cdot 2$ \\
\hline
\end{tabular}

Calvaria were precultured for $24 \mathrm{~h}$, then cultured with or without arachidonic acid and $\mathrm{Cu}^{2+}(5 \mu \mathrm{M})$ for $48 \mathrm{~h}$.

Results are shown as mean \pm SEM. Eleven calvaria in each treatment (from two litters).

Significantly different from each other: ${ }^{*} p<0.001$. 
Table $3 \quad\left[{ }^{3} \mathrm{H}\right]$-Labelled arachidonic acid metabolites produced by calvaria incubated with or without copper

\begin{tabular}{|c|c|c|c|c|c|}
\hline & $\begin{array}{l}\text { Control } \\
\text { dpm }\end{array}$ & $\begin{array}{l}\% \text { of } \\
\text { total dpm }\end{array}$ & $\begin{array}{l}\text { Copper } \\
d p m\end{array}$ & $\begin{array}{l}\% \text { of } \\
\text { total dpm }\end{array}$ & Ratio $\frac{\text { copper }}{\text { control }}$ \\
\hline \multicolumn{6}{|l|}{ Experiment 1} \\
\hline 6-keto-PGF $F_{1 \alpha}$ & 12938 & $48 \cdot 07$ & 18172 & $48 \cdot 71$ & $1 \cdot 40$ \\
\hline $\mathrm{TxB}_{2}$ & 1841 & 6.84 & 2341 & $6 \cdot 27$ & 1.27 \\
\hline $\mathrm{PGF}_{2 \alpha}$ & 2149 & $7 \cdot 98$ & 3025 & $8 \cdot 11$ & 1.41 \\
\hline $\mathrm{PGE}_{2}$ & 9985 & $37 \cdot 10$ & 13765 & $36 \cdot 90$ & $1 \cdot 38$ \\
\hline n & 10 & & 10 & & \\
\hline \multicolumn{6}{|l|}{ Experiment 2} \\
\hline 6-keto-PGF $F_{1 a}$ & 18670 & $50 \cdot 65$ & 25799 & $50 \cdot 37$ & $1 \cdot 38$ \\
\hline $\mathrm{TxB}_{2}$ & 3775 & $10 \cdot 24$ & 5168 & 10.09 & $1 \cdot 37$ \\
\hline $\mathrm{PGF}_{2 \alpha}$ & 2799 & $7 \cdot 59$ & 3988 & $7 \cdot 78$ & 1.42 \\
\hline $\mathrm{PGE}_{2}$ & 11614 & $31 \cdot 51$ & 16259 & $31 \cdot 74$ & 1.40 \\
\hline $\mathrm{n}$ & 8 & & 8 & & \\
\hline
\end{tabular}

Calvaria were prelabelled with $\left[{ }^{3} \mathrm{H}\right]-\mathrm{AA}$ and cultured with or without $\mathrm{Cu}^{2+}(5 \mu \mathrm{M})$ as outlined in 'Methods'. Labelled prostanoids were separated by HPLC as outlined in 'Methods'.

$\mathrm{dpm}=$ Disintegrations per minute.

Table 4 Effect on active resorption of increasing concentrations of $P G E_{2}$ in the presence of copper

\begin{tabular}{|c|c|c|c|c|c|}
\hline Control & $P G E_{2} 10^{-8} \mathrm{M}$ & $\Delta$ & Copper & $\begin{array}{l}P G E_{2} 10^{-8} \mathrm{M}+ \\
\text { copper }\end{array}$ & $\Delta$ \\
\hline $19 \cdot 1 \pm 0 \cdot 5$ & $23 \cdot 7 \pm 0 \cdot 9$ & $4 \cdot 6$ & $10 \cdot 7 \pm 1 \cdot 3$ & $11 \cdot 8 \pm 1 \cdot 2$ & $1 \cdot 1 \mathrm{p}<0 \cdot 005$ \\
\hline Control & $P G E_{2} 10^{-7} \mathrm{M}$ & $\Delta$ & Copper & $\begin{array}{l}P G E_{2} 10^{-7} \mathrm{M}+ \\
\text { copper }\end{array}$ & $\Delta$ \\
\hline $19 \cdot 1 \pm 0 \cdot 5$ & $27 \cdot 3 \pm 0 \cdot 8$ & $8 \cdot 2$ & $10 \cdot 7 \pm 1 \cdot 3$ & $15 \cdot 6 \pm 0 \cdot 5$ & $4.9 p<0.001$ \\
\hline Control & $P G E_{2} 10^{-6} \mathrm{M}$ & $\Delta$ & Copper & $\begin{array}{l}P G E_{2} 10^{-6} \mathrm{M}+ \\
\text { copper }\end{array}$ & $\Delta$ \\
\hline $19 \cdot 1 \pm 0 \cdot 5$ & $31 \cdot 4 \pm 1 \cdot 7$ & 12.3 & $10 \cdot 7 \pm 1 \cdot 3$ & $18 \cdot 5 \pm 1 \cdot 6$ & $7 \cdot 8 p<0.005$ \\
\hline
\end{tabular}

Calvaria were precultured for $24 \mathrm{~h}$, the medium changed, and prostaglandins added with or without $\mathrm{Cu}^{2+}(5 \mu \mathrm{M})$.

Percentage active resorption $\left({ }^{45} \mathrm{Ca}\right)$ is expressed as mean \pm SEM.

Significant differences between each treatment and its appropriate control are shown on right hand side.

Calvaria from two litters were pooled $(n=5$ each treatment).

$\Delta=$ Difference.

Table 5 Effect of copper on active resorption $\left({ }^{45} \mathrm{Ca}\right)$ in the presence of promoters of resorption

\begin{tabular}{|c|c|c|c|c|c|c|}
\hline Control & Arachidonic acid & $\Delta$ & Copper & $\begin{array}{l}\text { Arachidonic acid } \\
+ \text { copper }\end{array}$ & $\Delta$ & \\
\hline $\begin{array}{l}22 \cdot 6 \pm 0 \cdot 8 \\
(n=15)\end{array}$ & $\begin{array}{l}28 \cdot 8 \pm 1 \cdot 3 \\
(n=15)\end{array}$ & $+6 \cdot 2$ & $\begin{array}{l}12 \cdot 5 \pm 0 \cdot 6 \\
(n=15)\end{array}$ & $\begin{array}{l}16 \cdot 1 \pm 0 \cdot 6 \\
(n=15)\end{array}$ & $+3 \cdot 6$ & $\mathrm{p}<0 \cdot(005$ \\
\hline $\begin{array}{l}\text { Control } \\
24 \cdot 1 \pm 0 \cdot 8 \\
(n=14)\end{array}$ & $\begin{array}{l}P G E_{2} \\
42 \cdot 7 \pm 1 \cdot 4 \\
(n=14)\end{array}$ & $\begin{array}{l}\Delta \\
+18 \cdot 6\end{array}$ & $\begin{array}{l}\text { Copper } \\
13 \cdot 2 \pm 0 \cdot 4 \\
(n=14)\end{array}$ & $\begin{array}{l}P G E_{2}+\text { copper } \\
22 \cdot 5 \pm 0 \cdot 9 \\
(\mathrm{n}=14)\end{array}$ & $\begin{array}{l}\Delta \\
+9 \cdot 3\end{array}$ & $\mathrm{p}<0 \cdot 001$ \\
\hline $\begin{array}{l}\text { Copper } \\
17 \cdot 9 \pm 1 \cdot 9 \\
(n=9)\end{array}$ & $\begin{array}{l}P G F_{2 \alpha} \\
32 \cdot 1 \pm 1 \cdot 3 \\
(\mathrm{n}=9)\end{array}$ & $\begin{array}{l}\Delta \\
+14 \cdot 2\end{array}$ & $\begin{array}{l}\text { Copper } \\
9 \cdot 9 \pm 1 \cdot 1 \\
(n=9)\end{array}$ & $\begin{array}{l}P G F_{2 a}+\text { copper } \\
17 \cdot 3 \pm 0 \cdot 6 \\
(n=9)\end{array}$ & $\begin{array}{l}\Delta \\
+7 \cdot 4\end{array}$ & $\mathrm{p}<0 \cdot 001$ \\
\hline
\end{tabular}

Calvaria were precultured for $24 \mathrm{~h}$, medium changed, and additions made as shown. (Arachidonic acid (10 $\left.0^{-5} \mathrm{M}\right)$, PGE 2 , or $\operatorname{PGF}_{2 \alpha}\left(10^{-5} \mathrm{M}\right)$ and $\left.\mathrm{Cu}^{2+}(5 \mu \mathrm{M})\right)$.

Percentage active resorption $\left({ }^{45} \mathrm{Ca}\right)$ is expressed as mean $\pm \mathrm{SEM}$.

Significant differences between each treatment and its appropriate control are shown on right hand side. Ten calvaria in each treatment (from two litters). 
material which may have corresponded to $\mathrm{PGE}_{2}$ and $\mathrm{PGF}_{2 \alpha}$ metabolites, but these were not identified by authentic $\left[{ }^{3} \mathrm{H}\right]$-labelled compounds. The results of these two separate experiments are shown in Table 3 . In both experiments there was evidence that $\mathrm{Cu}^{2+}$ $(5 \mu \mathrm{M})$ enhanced the production of each of the prostanoids identified. The relative amounts of 6-keto-PGF $1 \alpha, \mathrm{PGF}_{2 \alpha}, \mathrm{PGE}_{2}$, and $\mathrm{TxB}_{2}$ were unchanged by exposure to $\mathrm{Cu}^{2+}$ in the two experiments. The amount of $\left[{ }^{3} \mathrm{H}\right]-\mathrm{PGE}_{2}$ was probably underestimated, since experiments using chromatographically pure $\left[{ }^{3} \mathrm{H}\right]-\mathrm{PGE}_{2}$ showed that, under the culture conditions employed, $24.8 \%$ was converted to $\mathrm{PGA}_{2}$.

The effect of copper in combination with prostaglandins was investigated by adding increasing amounts of $\mathrm{PGE}_{2}\left(10^{-8} \mathrm{M}\right.$ to $\left.10^{-6} \mathrm{M}\right)$ to calvaria cultured with or without $\mathrm{Cu}^{2+}(5 \mu \mathrm{M})$. The results outlined in Table 4 compare the ability of $\mathrm{PGE}_{2}$ at each concentration to increase resorption under these conditions. As can be seen, the reduced resorption in the presence of $\mathrm{Cu}^{2+}$ cannot be overcome by increasing concentrations of $\mathrm{PGE}_{2}$. Arachidonic acid $\left(10^{-5} \mathrm{M}\right)$ or a higher concentration of $\mathrm{PGE}_{2}\left(10^{-5} \mathrm{M}\right)$ or $\mathrm{PGF}_{2 \alpha}\left(10^{-5} \mathrm{M}\right)$ were also unable to reverse the effect of $\mathrm{Cu}^{2+}$ (Table 5).

Calvaria were cultured with or without $\mathrm{Cu}^{2+}$ with the addition of indomethacin at a concentration $\left(7.0 \times 10^{-7} \mathrm{M}\right)$ sufficient to inhibit prostaglandin synthesis. ${ }^{17} \mathrm{Cu}^{2+}$ decreased the ${ }^{45} \mathrm{Ca}$ resorption to $77.4 \%$ of that seen with indomethacin alone $(\mathrm{p}<0 \cdot 05, \mathrm{n}=5)$.

\section{Discussion}

A number of studies have confirmed that prostaglandins, particularly those of the $E$ series and $F$ series, and prostacyclin are potent stimulators of bone resorption in vitro. ${ }^{12}{ }^{20}$ Mouse calvaria produce prostaglandins under appropriate culture conditions. ${ }^{1314}$ Our own studies would indicate the involvement of these compounds in maintaining basal bone resorption in vitro, since non-toxic concentrations of indomethacin $\left(<=7.0 \times 10^{-7} \mathrm{M}\right)$ decreased both bone resorption and prostaglandin production. ${ }^{17}$ Under normal culture conditions the relative amounts of $\left[{ }^{3} \mathrm{H}\right]$-labelled prostanoids released by calvaria prelabelled with $\left[{ }^{3} \mathrm{H}\right]$-arachidonic acid were in the order 6-keto-PGF ${ }_{1 \alpha}>\mathrm{PGE}_{2}=$ $\mathrm{PGF}_{2 \alpha}$ and $\mathrm{TxB}_{2}$. These results are generally in agreement with those of Voelkel et al. ${ }^{13}$ except that there was no evidence for the production of $\left[{ }^{3} \mathrm{H}\right]-6$, 15-diketo-PGF $1 \alpha$.

Although non-toxic levels of $\mathrm{Cu}^{2+}(5 \mu \mathrm{M})$ lowered bone resorption $(p<0.001)$, the synthesis of
$\mathrm{PGE}_{2}, \mathrm{PGF}$, or 6-keto-PGF $1 \alpha$ was not decreased (Table 1). Rather, the levels of these prostaglandins appeared to increase. Moreover, when $\left[{ }^{3} \mathrm{H}\right]-$ arachidonic acid was added to the culture medium in the presence of $\mathrm{Cu}^{2+}$, there was again evidence of an increase in the synthesis of all these prostaglandins and also in $\mathrm{TxB}_{2}$ (Table 3). There was, however, no effect of $\mathrm{Cu}^{2+}$ on the relative amounts of these four prostanoids, in contrast to the findings of Maddox, ${ }^{11}$ who found an increase in $\mathrm{PGF}_{2 \alpha}$ at the expense of $\mathrm{PGE}_{2}$ in sheep seminal vesicle homogenates incubated with $\mathrm{Cu}^{2+}(100 \mu \mathrm{M})$. The increase in total prostanoid synthesis did not appear to be caused by an increase in substrate availability, since the mobilisation of $\left[{ }^{3} \mathrm{H}\right]$-arachidonate from prelabelled calvaria was almost identical in the presence and absence of $\mathrm{Cu}^{2+}$. These results may therefore be interpreted as suggesting that the influence of $\mathrm{Cu}^{2+}$ is to enhance the activity of cyclo-oxygenase in this in-vitro system.

The possibility that copper was affecting the action of prostaglandins on bone resorption was also considered. Arachidonic acid $\left(10^{-5} \mathrm{M}\right)$ increased both prostaglandin production and active resorption (Table 2). This arachidonic acid-stimulated resorption was significantly reduced in the presence of $\mathrm{Cu}^{2+}$ (Table 5) despite an increase in PGF production (Table 2), that is, the production of prostaglandins was increased, but their action was inhibited by $\mathrm{Cu}^{2+}$. This observation was confirmed when either $\mathrm{PGE}_{2}$ or $\mathrm{PGF}_{2 \alpha}$ was added to $\mathrm{Cu}^{2+}$. Increasing concentrations of $\mathrm{PGE}_{2}\left(10^{-8} \mathrm{M}\right.$ to $\left.10^{-5} \mathrm{M}\right)$ and high concentrations of $\mathrm{PGF}_{2 \alpha}\left(10^{-5} \mathrm{M}\right)$ were unable to reverse the inhibition of resorption caused by $\mathrm{Cu}^{2+}$ (Tables 4 and 5).

These results suggest that $\mathrm{Cu}^{2+}$ may 'uncouple' the resorptive response to prostaglandins, but its exact mechanism of action cannot be deduced from these experiments. It is likely that $\mathrm{Cu}^{2+}$ has more than one locus of action. This was suggested by experiments where calvaria were cultured with indomethacin $\left(7.0 \times 10^{-7} \mathrm{M}\right)$ with and without $\mathrm{Cu}^{2+}$ $(5 \mu \mathrm{M})$. In these experiments $\mathrm{PGE}_{2}$ release was lowered to $<6.0 \%$ of the amounts in cultures without indomethacin. ${ }^{17}$ With the further addition of $\mathrm{Cu}^{2+}$ resorption was decreased below that seen with indomethacin alone, suggesting an inhibitory action independent of prostaglandin synthesis. This could possibly be due to a direct effect on the activity of $\beta$-glucuronidase and perhaps other lysosomal enzymes implicated in bone resorption. ${ }^{21}$ $\beta$-Glucuronidase activity released into the media from calvaria and measured by the method of Willcox ${ }^{22}$ was decreased to $86 \%$ control values in the presence of $\mathrm{Cu}^{2+}(p<0.001, n=24)$. The complexity of the resorption process was evident also 
from experiments using parathormone stimulation of resorption. The parathormone-stimulated resorption was virtually unaffected by the presence of $\mathrm{Cu}^{2+}(5 \mu \mathrm{M})$ in contrast to the resorption stimulated by prostaglandins (results not shown).

This study does not suggest any simple interpretation of the action of copper as an anti-inflammatory agent in inflammatory diseases such as rheumatoid arthritis, ankylosing spondylitis, and periodontal disease. It gives some indication of the need for care in devising experimental models for these conditions, since the possibility of an anti-inflammatory (or antiresorptive activity) of copper in opposing prostaglandin action rather than synthesis has not always been considered. ${ }^{23}$ Thus the high concentrations of both prostaglandins ${ }^{24} 25$ and $\mathrm{Cu}^{2+26}$ in rheumatoid arthritis synovial fluid cannot necessarily be interpreted as suggesting that $\mathrm{Cu}^{2+}$ has no anti-inflammatory activity.

In summary, the mechanism of action of $\mathrm{Cu}^{2+}$ in decreasing bone resorption appears complex. Evidence has been presented to show that the release of prostaglandins is not reduced, but rather enhanced, possibly due to a non-specific effect on the activity of cyclooxygenase. It would appear that $\mathrm{Cu}^{2+}$ not only impedes the action of exogenous prostaglandins on bone but may also inhibit resorption mediated by lysosomal enzymes or other as yet undefined mechanisms.

This work is supported by a grant from the Medical Research Council of New Zealand and the Ruth Spencer Medical Research Fellowship (J.M.K.). We wish to thank the staff of the Animal Laboratories for supplying mice, and Mrs Patricia James and Mrs Lye Yee for secretarial assistance.

\section{References}

1 Scudder P R, Al-Timimi D, McMurray W, White A G, Zoob B C, Dormandy T L. Serum copper and related variables in rheumatoid arthritis. Ann Rheum Dis 1978; 37: 67-70.

2 Jayson M I V, Davis P, Whicher J T, Walters G. Serum copper and caeruloplasmin in ankylosing spondylitis, systemic sclerosis, and morphea. Ann Rheum Dis 1976; 35: 443-5.

3 Lipkin G, Hermann F, Mandol L. Studies on serum copper. II-The copper levels in relation to corticosteroid administration. J Invest Dermatol 1962; 39: 547-50.

4 Milanino R, Passarella E, Velo G P. Adjuvant arthritis in young copper-deficient rats. Agents Actions 1978; 8: 623-8.

5 Sweeney S C. Alteration in tissue and serum caeruloplasmin concentration associated with inflammation. J Dent Res 1967 46: 1171-6.

6 Milanino R, Mazzoli S, Passarella E, Tarter G, Velo G P. Carrageenan oedema in copper-deficient rats. Agents Actions 1978; 8: 618-22.
7 Milanino R, Conforti A, Fracasso M E, et al. Concerning the role of endogenous copper in the acute inflammatory process. Agents Actions 1979; 9: 581-8.

8 Sorenson J R J. Copper chelates as possible active forms of the antiarthritic agents. J Med Chem 1976; 19: 135-48.

9 Beveridge S J, Whitehouse M W, Walker W R. Lipophilic copper (II) formulations: some correlations between their composition and anti-inflammatory/antiarthritic activity when applied to the skin of rats. Agents Actions 1982; 12: 225-31.

10 Wilson T, Katz J M, Gray D.H. Inhibition of active bone resorption by copper. Calcif Tissue Int 1981; 33: 35-9.

11 Maddox I S. The role of copper in prostaglandin synthesis. Biochim Biophys Acta 1973; 306: 74-81.

12 Dietrich J W, Goodson J M, Raisz L G. Stimulation of bone resorption by various prostaglandins in organ culture. Prostaglandins 1975; 10: 231-40.

13 Voelkel E F, Tashjian A H Jr, Levine L. Cyclooxygenase products of arachidonic acid metabolism by mouse bone in organ culture. Biochim Biophys Acta 1980; 620: 418-28.

14 Katz J M, Wilson T, Skinner S J M, Gray D H. Bone resorption and prostaglandin production by mouse calvaria in vitro: response to exogenous prostaglandins and their precursor fatty acids. Prostaglandins 1981; 22: 537-51.

15 Liggins G C, Campos G A, Roberts C M, Skinner S J M Production rates of prostaglandin F, 6-keto-PGF ${ }_{1 \alpha}$ and thromboxane $\mathrm{B}_{2}$ by perifused human endometrium. Prostaglandins 1980; 19: 461-77.

16 Powell W S. Rapid extraction of oxygenated metabolites of arachidonic acid from biological samples using octadecylsilyl silica. Prostaglandins 1980; 20: 947-57.

17 Katz J M, Skinner S J M, Wilson T, Gray D H. The in vitro effect of indomethacin on basal bone resorption, on prostaglandin production and on the response to added prostaglandins Prostaglandins 1983; 26: 545-55.

18 Alam I, Ohuchi K, Levine L. Determination of cyclooxygenase products and prostaglandin metabolites using high-pressure liquid chromatography and radioimmunoassay. Anal Biochem 1979; 93: 339-45.

19 Spjøtvoll E, Stoline M R. An extension of the T-method of multiple comparison to include the cases with unequal sample sizes. J Am Statist Assoc 1973; 68: 975-8.

20 Ali N N, Auger D W, Bennett A, Edwards D A, Harris M. Effect of prostacyclin and its breakdown product 6-oxo-PGF F $_{1 \alpha}$ on bone resorption in vitro. In: Vane J R, Bergström S, eds. Prostacyclin. New York: Raven Press, 1979: 179-85.

21 Eilon G, Raisz L G. Comparison of the effects of stimulators and inhibitors of resorption on the release of lysosomal enzymes and radioactive calcium from fetal bone in organ culture. Endocrinology 1978; 103: 1969-75.

22 Willcox $\mathrm{P}$. Secretion of $\beta$ - $\mathrm{N}$-acetylglucosaminidase isoenzymes by normal human fibroblasts. Biochem $J$ 1978; 173: 433-9.

23 Dollwet H H A, Schmidt S P, Seeman R E. Anti-inflammatory properties of copper implants in the rat paw edema: a preliminary study. Agents Actions 1981; 11: 746-9.

24 Trang $L E$, Granström E, Lövgren $O$. Levels of prostaglandins $F_{2 \alpha}$ and $E_{2}$ and thromboxane $B_{2}$ in joint fluid in rheumatoid arthritis. Scand J Rheumatol 1977; 6: 151-4.

25 Brodie M J, Parke A, Gordon D, Hensby C N. 6-oxoprostaglandin $\mathbf{F}_{1 \alpha}$ in inflammatory joint fluid. In: Lewis $\mathbf{P} \mathbf{J}$, O'Grady J, eds. Clinical pharmacology of prostacyclin. New York, Raven Press, 1981: 117-20.

26 Scudder P R, McMurray W, White A G, Dormandy T L. Synovial fluid copper and related variables in rheumatoid and degenerative arthritis. Ann Rheum Dis 1978; 37: 71-2. 